Article

\title{
Computational Prediction of Susceptibility to Biofilms Growth: Two-Dimensional Analysis of Critical Construction Details
}

\author{
Václav Kočí ${ }^{1,2} \mathbb{D}$, Jan Kočí ${ }^{1, * \mathbb{D}}$, Jiří Maděra ${ }^{1}$, Jaroslav Žák ${ }^{2}$ and Robert Černý ${ }^{1}{ }^{\mathbb{D}}$ \\ 1 Department of Materials Engineering and Chemistry, Faculty of Civil Engineering, Czech Technical \\ University in Prague, Thákurova 7/2077, 16629 Prague 6, Czech Republic; vaclav.koci@fsv.cvut.cz (V.K.); \\ madera@fsv.cvut.cz (J.M.); cernyr@fsv.cvut.cz (R.Č.) \\ 2 Institute of Technology and Business in České Budějovice, Okružní 517/10, 37001 České Budějovice, Czech \\ Republic; zak@mail.vstecb.cz \\ * Correspondence: jan.koci@fsv.cvut.cz; Tel.: +420-2-2435-7130
}

Received: 11 December 2019; Accepted: 4 January 2020; Published: 7 January 2020

\begin{abstract}
Retrofitting of historical and traditional buildings is an effective thermal protection measure. The presence of thermal insulation in the composition of building envelopes might, however, bring some shortages due to a decrease of exterior surface temperatures or possible water vapor condensation. These shortages can improve living conditions for various microorganisms on the exterior surfaces, especially in the case of interior thermal insulation systems that are typical with thermal bridges and thus supply the surface with heat to a greater extent. This paper, therefore, aims at the investigation of hygrothermal conditions in selected critical construction details and evaluates the results from the point of view of potential biofilms growth. Two-dimensional modeling of coupled heat and moisture is applied and the hygrothermal patterns are evaluated based on an adjusted isopleth growth model. The results showed that the duration of favorable conditions for biofilms growth is relatively low, accounting for less than $180 \mathrm{~h}$ in the worst-case scenario. It means the exterior surfaces of historical buildings provided with interior thermal insulation systems are not threatened by biofilms growth. Anyway, other negative aspects have been revealed that should be treated individually. Possible wood decay or increased hygrothermal straining are the typical examples in that respect.
\end{abstract}

Keywords: biofilms growth; computational modeling; hygrothermal patterns; brick masonry; interior thermal insulation; climatic data; mineral wool; wood fiber board

\section{Introduction}

Thermal protection of buildings belongs among the most important tasks of current building physics. Being governed by global policies, the protection represents a powerful measure for minimizing the overall energy consumption as heating of residential buildings accounts for a significant part of it [1]. The European Union with its directives clearly proves how energy consumption can be efficiently moderated. In the light of the above mentioned, the last directive, known as EPBD II (Energy Performance Building Directive II) [2] introduced so-called nearly zero energy buildings. Among others, most EU countries increased their requirements on thermal protection of building as a consequence.

The stringent requirements on thermal insulating properties of building envelopes have resulted in utilization of modern building materials with high thermal resistance such as modern bricks $[3,4]$, autoclaved aerated concretes [5], various types of excellent thermal insulations, or the construction and operation systems of houses have been improved to reach low energy or even passive standards $[6,7]$. 
At the same time, old buildings have been retrofitted by means of the addition of extra insulation layers. This retrofitting resulted in better thermal protection of buildings and thus to a reduction of heating energy. On the other hand, reducing the heat flux through the envelopes, thermal insulations have also contributed to a decrease in the external surface temperatures of walls [8]. As a consequence, evaporation of possible condensed water has been slowed down, which has led to a substantial improvement of living conditions for various microorganisms, thus to increased risks of biodegradation of surface layers. This shortage concerns especially interior thermal insulation systems [9], which are unavoidable in the case of retrofitting of historical and traditional buildings that might account for up to $40 \%$ of the building stock [10]. There is a simple explanation of this phenomenon. Since the interior thermal insulation systems are not as efficient in thermal bridges elimination [11,12], the walls might locally face an increased heat flux and thus might be exposed also to increased temperatures which, in combination with the condensed water [13], might even intensify the risk of biodegradation. In case of critical construction details from the point of view of thermal bridging such as beam joints, building corners, or window jambs, these risks of creation of optimal hygrothermal patterns may be even higher. The importance of these problems has been also mentioned in several studies published so far. For instance, Vereecken and Roels [14] pointed out in their study the increased hygric straining of masonry and wooden beam ends when interior thermal insulation is applied. They identified the lower drying potential and increased risk of condensation due to low temperature as the main causes of the increased straining. Orlik-Kożdon [12] mentioned in her study risks of biological corrosion related to interior thermal insulation systems, especially when larger thicknesses of insulation material and high diffusion parameters are used.

Since the biofilms on the surface of building materials may cause a color change of the substrate, mechanical stress, or may accumulate atmospheric pollutants which result in a certain modification of aesthetical or functional properties of the building envelopes, several techniques have been also developed to remove the biofilms, if they appear. There are chemical treatments studied that are supposed to remove the existing biofilms. Guiamet et al. [15], for instance, investigated an intervention of biofilms on selected natural stones using benzalkonium chloride solution. Comparing the biofilms' composition before and after the treatment, they found that several organisms were effectively removed, but there were still some of them that remained unaffected and other biocides should be therefore tested-water repellents or consolidants belong among other chemical treatments that might be used [16]. There are also mechanical ways of intervention being based on mechanical cleaning of the surface. However, there is a serious risk of surface recolonization as mentioned in the work published by Jurado et al. [17]. A mass loss is the other disadvantage that goes along with this technique. It is also possible to use biocidal or fungicidal additives $[18,19]$ in plasters composition or apply protective coatings [20]. Unfortunately, these measures might always not conform to the cultural heritage conservation principles that mostly make a point of maintaining the original compositions, formulas, or procedures. Passive techniques can be therefore more advantageous from this point of view, being based on a selection of suitable material combinations or adjusting a constructional solution.

Based on the above mentioned, the main objective of this paper is to analyze selected construction details that are characteristic of heat leakage. The analysis is supposed to reveal the possible shortages of walls retrofitting from the point of view of risks of biodegradation of exterior surface layers. Two-dimensional computational modeling of hygrothermal performance of selected details exposed to dynamic weather conditions is used for that purpose. These details are provided with selected thermal insulation systems suitable for interior applications.

\section{Critical Construction Details}

Two critical details were selected for the investigations within this paper: a wood beam end joint to brick masonry and a window jamb. In order to accommodate all the related transport problems and specifics, these assemblies were assumed in the computational analyses as two-dimensional. While the heat and moisture transport across the beam joint detail was solved in a vertical plane, the window 
jamb was investigated in a horizontal cross-section. The scheme of the critical details analyzed is shown in Figures 1 and 2.

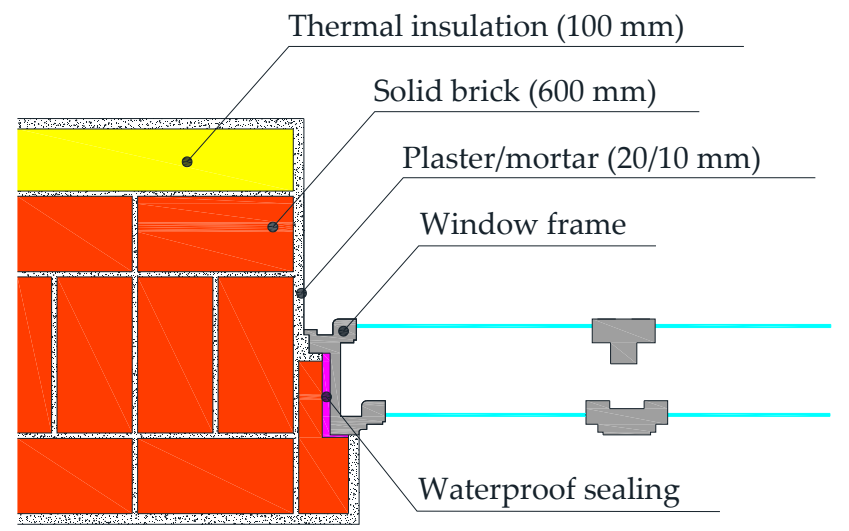

Figure 1. Scheme of the window jamb with the window frame-a horizontal cross-section.

Solid brick $(450 \mathrm{~mm})$

Thermal insulation $(100 \mathrm{~mm})$

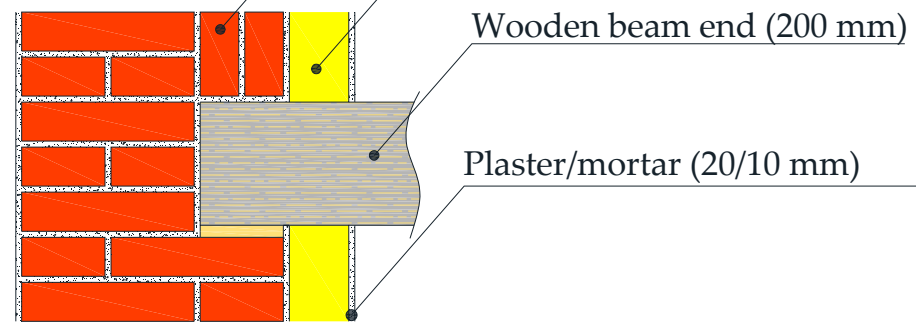

Figure 2. Scheme of the masonry with the wooden beam end-a vertical cross-section.

Two types of thermal insulations suitable for interior applications were assumed within this research: mineral wool treated to exhibit hydrophilic properties and wood fiber board. Both the plaster and the mortar are on a lime cement base.

\section{Biofilms}

According to the latest literature review, the biodegradation processes of various building materials are well-known as they have been studied intensively. A study of biodegradation was reported, e.g., by Vojtkova [21], who investigated algae growth and its effects on natural stones. Speaking of natural stones, microbial activities of bacteria, microalgae, cyanobacteria, and filamentous fungi on limestone were also studied, e.g., by Rosado [22]. A study of natural stones was also reported by Guillitte and Dreesen [23]. The research presented by Segers et al. [24] deals with the growth of fungi on gypsum. Biodegradation of mortars was investigated by Shirakawa et al. [25] or Tran and Hoang [26,27]. Concrete has also become a subject of interest [28] as well as bricks [23,29]. Another group of authors aims at the biodegradation of paintings as facades finishing $[30,31]$ or as a subject of cultural heritage $[32,33]$.

The nature of surface building materials plays is crucial as mineral materials are more frequently colonized by microorganisms than organic ones. According to Barberousse et al. [34], physical parameters such as roughness or porosity are of great importance in that respect. However, other parameters such as biofilms compositions, temperature, relative humidity, solar radiation [35], and chemical composition [36] of substrates are important as well. It is also known that finish 
materials with higher water absorption are prone to biological colonization and degradation [37]. Based on the above mentioned, claddings might be excluded from the group of potentially vulnerable elements as they are usually made of polished stones with a small roughness or of materials having sintered structure and thus very low porosity. On the other hand, plasters can be considered to be most susceptible to biodegradation among traditional surface materials, especially when biodetergents are not present.

Algae and cyanobacteria are the major microbial biomass of biofilms in Europe [30,38]. They cover mostly mineral materials as shown in Figure 3, where algae patches are clearly seen.
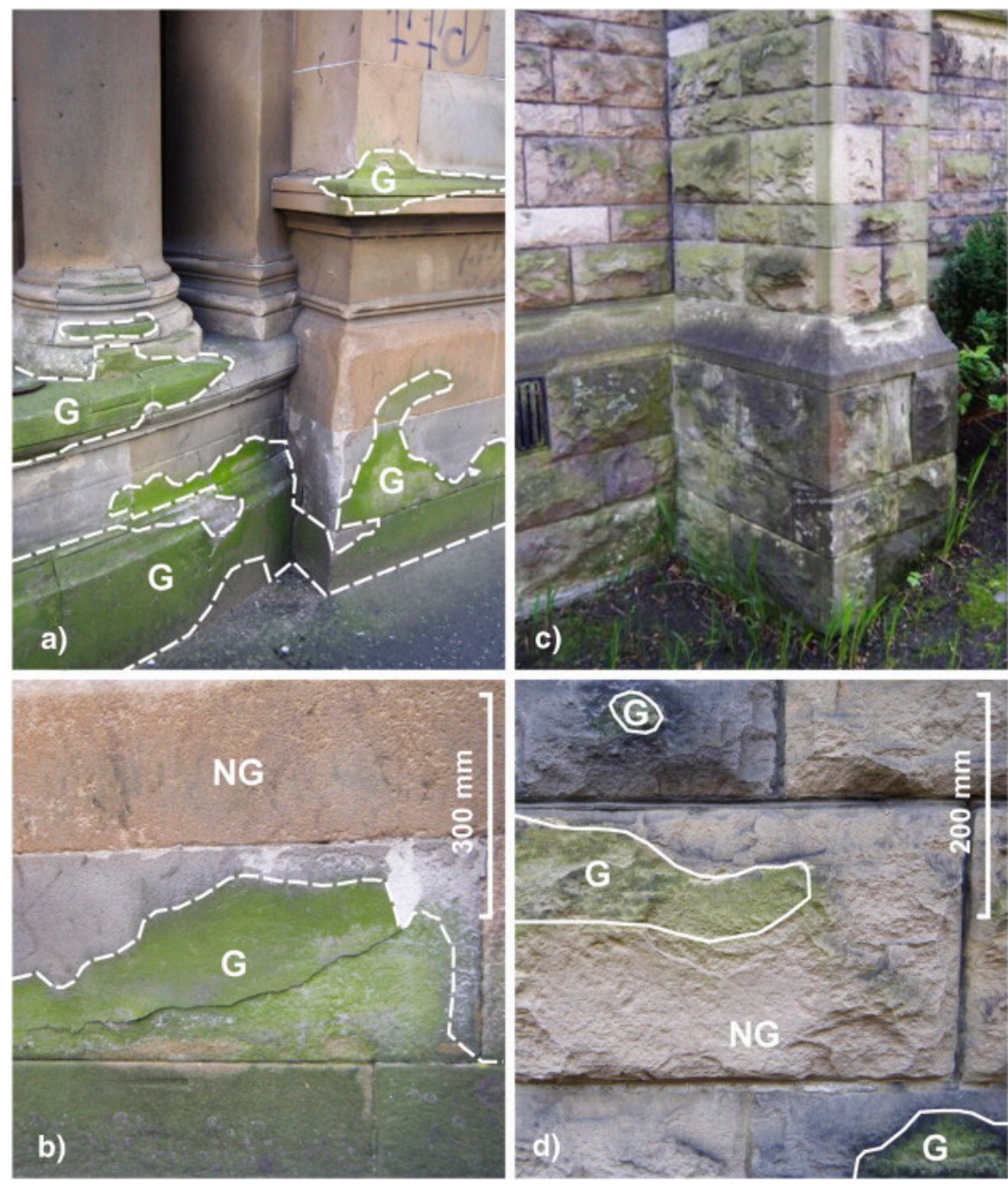

Figure 3. Examples of colonization by green algae. The green algal patches are demarcated using dotted/solid lines and labelled 'G': (a) the ashlar walls of Ewart's building in Belfast, (b) details of an ashlar block in Giffnock stone from the same building, (c) the rock-faced walls of All Souls Church in Belfast, (d) detail of a rock-faced, Scrabbo block from All Souls Church in Belfast. Reprinted from Science of the Total Environment, 442, N. A. Cutler, H. A. Viles, S. Ahmad, S. McCabe, B. J. Smith, Algal 'greening' and the conservation of stone heritage structures, 152-164, Copyright (2013), with permission from Elsevier.

The microscopic pictures of algae (Hematococcus pluvialis, Klebsormidium sp.) and cyanobacteria (genus Nostoc, Anabaena), obtained using light microscope equipped with a digital camera system, are shown in Figure 4. 


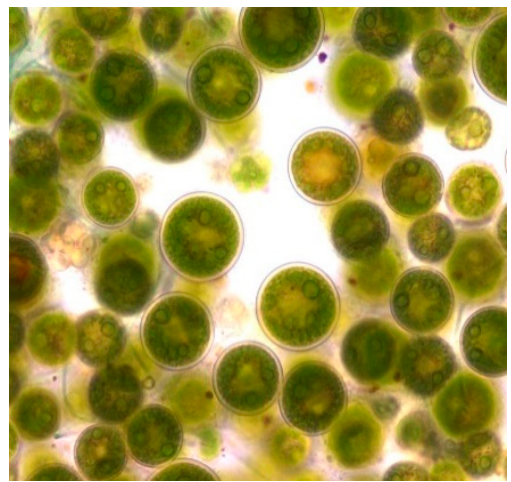

(a)

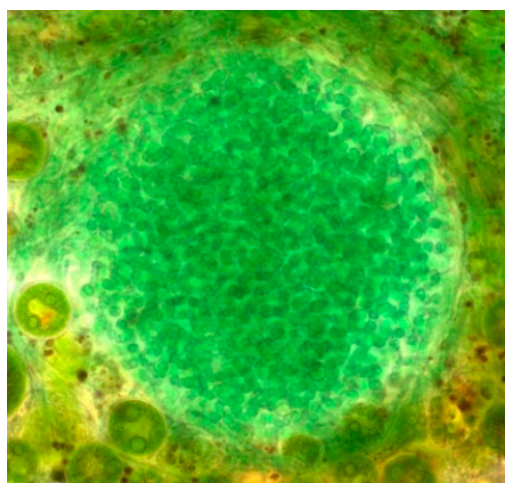

(c)

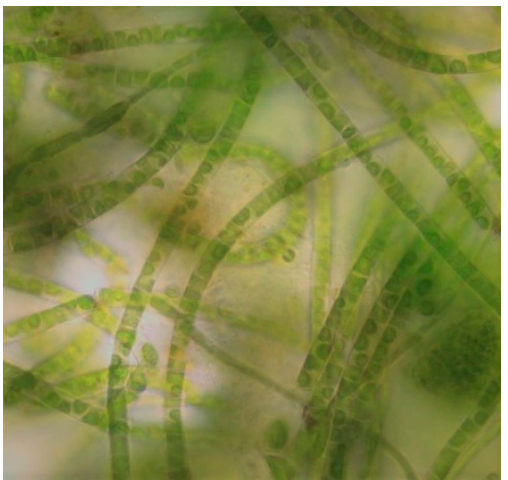

(b)

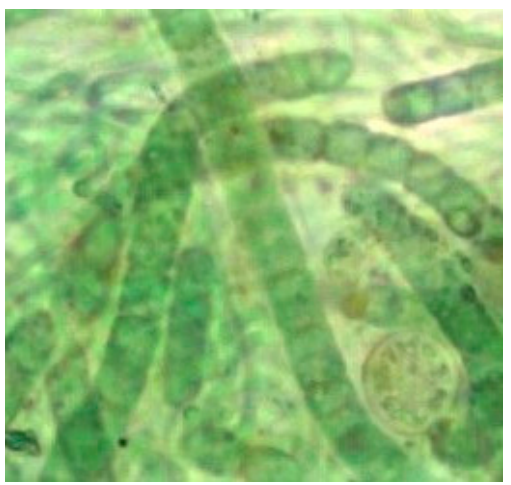

(d)

Figure 4. Algal species Hematococcus pluvialis (a), Klebsormidium sp. (b), cyanobacteria of genus Nostoc (c), and Anabaena (d). Reprinted from MATEC Web of Conferences, 282, K. Kobetičová, J. Nábělková, V. Kočí, Identification of biofilm composition covering lime-based materials, Article No. 20267 (2019), (Licensed under CC BY 4.0) https://creativecommons.org/licenses/by/4.0/.

The biofilms growth rate conditions are very specific, being governed by hygrothermal patterns mostly and time of exposure. The precise temperature and relative humidity thresholds that condition the growth can be determined experimentally by means of observation of the biofilms' growth when exposed to particular hygrothermal conditions. The optimal growth models based on hygrothermal patterns were summarized by Vereecken and Roels [39] who processed a comprehensive review on this topic. Isopleth models, using relations between relative humidity, temperature, and exposure time to separate favorable and unfavorable hygrothermal conditions, belong among the favorite tools used for prediction of growth of molds, fungi, and other microorganisms. Within this paper, the ESP-r model proposed by Clarke and Rowan $[40,41]$ is used to estimate the favorable RH threshold for the biofilm growth depending on the temperature. Depending on the categories, various thresholds are set: highly xerophilic (A), xerophilic (B), and hydrophilic (C). Since this model is proposed to evaluate risks of mold growth, further modifications were adopted within this paper to adjust to particular biofilm composition. The optimal temperature range was reduced from the originally proposed 5-30 ${ }^{\circ} \mathrm{C}$ to $20-26^{\circ} \mathrm{C}$ according to Dubosc el al. [42]. Additionally, the growth is limited only to daylight periods. The favorable growth conditions including their analytical formulations are given in Figure 5. The curves presented in this figure were constructed by approximation of the experimental data using polynomial functions of the third order. They were taken as presented by Rowan et al. [40]. The altering trend might be explained by low a number of experimental data sets as each curve was plotted based on five or six points. 


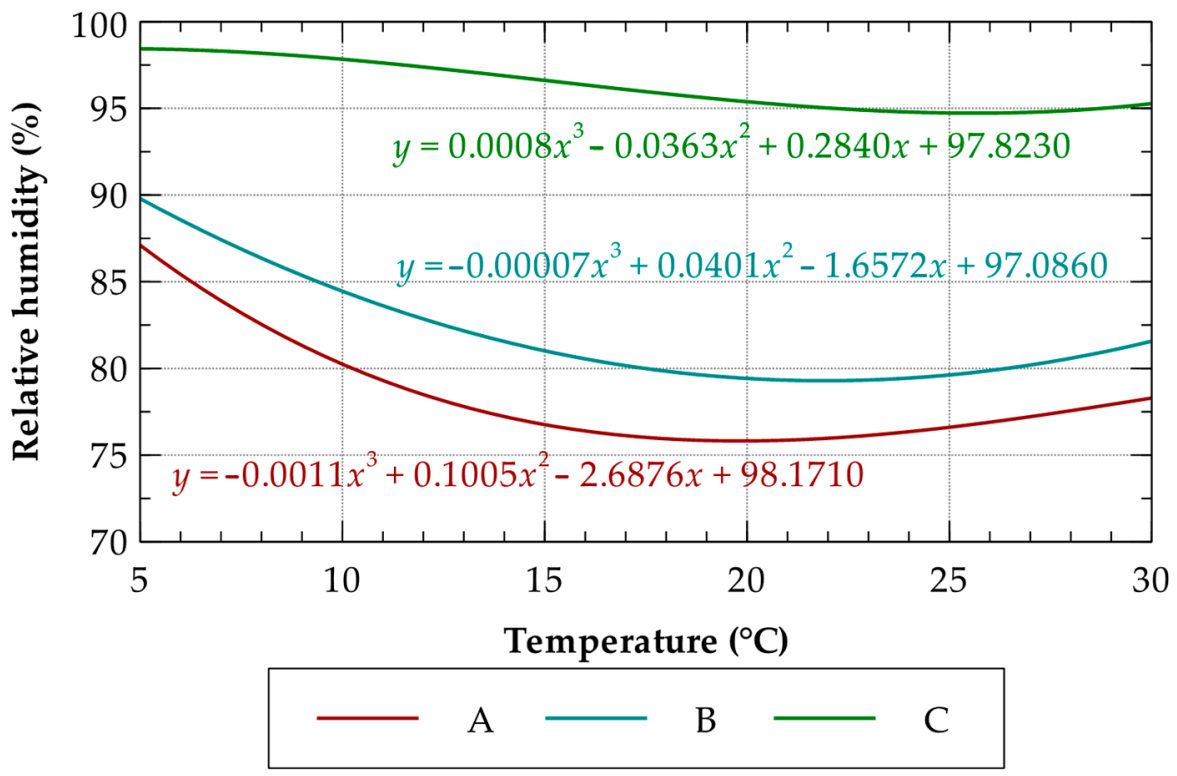

Figure 5. Favorable growth conditions.

\section{Computational Modeling of Hygrothermal Performance}

Computational modeling is applied to simulate and predict the distribution of moisture and temperature fields upon the reference weather year in the assemblies selected (Figures 1 and 2). A specification of the model and all the input parameters is described in detail in the following subsections.

\subsection{Mathematical Model}

The theory of moisture and heat transport processes has been known since the 1940s when the first models were introduced. In the following decades, the original models were further modified and extended into current forms. The model presented by Künzel belongs among the most popular ones, being represented by the two-phase moisture mass balance equation and the enthalpy-based heat balance equation, respectively. Because this model still contains several weak points that might be reflected in results produces, it was further modified by Madera et al. [43], who used the partial pressure of water vapor as a primary variable and introduced weight functions for precise distinguishing between particular moisture phases. The balance equations are then formulated as

$$
\begin{gathered}
\rho_{w} \frac{\mathrm{d} w}{\mathrm{~d} p_{v}} \frac{\partial p_{v}}{\partial t}=\operatorname{div}\left[\left(B D_{w} \rho_{w} \frac{\mathrm{d} w}{\mathrm{~d} p_{v}}+A \delta_{p}\right) \operatorname{grad} p_{v}\right], \\
\frac{\mathrm{d} H}{\mathrm{~d} T} \frac{\partial T}{\partial t}=\operatorname{div}(\lambda \operatorname{grad} T)+L_{v} \operatorname{div}\left[A \cdot \delta_{p} \operatorname{grad}\left(p_{v}\right)\right],
\end{gathered}
$$

where $\rho_{w}\left(\mathrm{~kg} \cdot \mathrm{m}^{-3}\right)$ is the water density, $w\left(\mathrm{~m}^{3} \cdot \mathrm{m}^{-3}\right)$ is the water content, $p_{v}(\mathrm{~Pa})$ is the partial pressure of water vapor in the air, $t(\mathrm{~s})$ is the time, $D_{w}\left(\mathrm{~m}^{2} \cdot \mathrm{s}^{-1}\right)$ is the moisture diffusivity, $\delta_{p}(\mathrm{~s})$ is the water vapor permeability, $H\left(\mathrm{~J} \cdot \mathrm{m}^{-3}\right)$ is the enthalpy density, $T(\mathrm{~K})$ is the temperature, $\lambda\left(\mathrm{W} \cdot \mathrm{m}^{-1} \cdot \mathrm{K}^{-1}\right)$ is the thermal conductivity, $L_{v}\left(\mathrm{~J} \cdot \mathrm{kg}^{-1}\right)$ is the latent heat of evaporation of water, and $A, B \in<0 ; 1>$ are transition coefficients between the liquid and gaseous phases of water, which give the weight to each phase according to the current moisture content.

The model was developed, calibrated, and validated based on experimental results obtained using a laboratory semi-scale experiment. Within this experiment, a wall segment, mounted by a set of temperature and relative humidity probes, was exposed to a controlled environment from both sided that was supposed to imitate the exterior and interior conditions. The measured profiles were 
then compared to those obtained computationally, being calibrated by adjusting the heat and moisture exchange coefficients within the admissible range. The very good agreement was shown as the $R^{2}$ of selected quantities observed was between 0.9687 and 0.9888 [44].

The model was implemented in the computer code HM Transport 2.0 that was also used for simulations within this paper. The HM Transport 2.0 is a scientific package developed at Department of Materials Engineering and Chemistry, Faculty of Civil Engineering, Czech Technical University in Prague. It works on a similar basis as other commercial software such as WUFI Pro (v6.4, Frauenhofer IBP, Holzkirchen, Germany), Delphin (v6, Bauklimatik Dresden, Dresden, Germany), or EnergyPlus (v9.2.0, The Board of Trustees of the University of Illinois and The Regents of the University of California through Ernest Orlando Lawrence Berkeley National Laboratory, Chicago, USA), but its open-source code allows it to be used and adapted to various problems related to heat and moisture transport in building physics problems.

\subsection{Material Properties}

The quality of material properties, as one of the input parameters, plays a significant role in the accuracy of results produced using the computational modeling technique. It means that experimental determination of material properties is more appropriate than exploiting generic data or data originating from public material databases. Therefore, all the material properties presented in this paper were determined experimentally in the laboratories of the Department of Materials Engineering and Chemistry, Faculty of Civil Engineering, Czech Technical University in Prague, following the methodology described in Refs. $[45,46]$. The summary is given in Table 1 and Figures 6 and 7.

Table 1. Summary of material properties.

\begin{tabular}{|c|c|c|c|c|c|}
\hline & $\begin{array}{c}\text { Solid Brick } \\
{[47]}\end{array}$ & Wood & $\begin{array}{c}\text { Lime Cement } \\
\text { Mortar/Plaster [48] }\end{array}$ & $\begin{array}{c}\text { Mineral Wool } \\
{[45]}\end{array}$ & $\begin{array}{c}\text { Wood Fiber } \\
\text { Board [49] }\end{array}$ \\
\hline Bulk density $\left(\mathrm{kg} \cdot \mathrm{m}^{-3}\right)$ & 1831 & 417 & 1244 & 70 & 54 \\
\hline Open porosity (\%) & 27.09 & 35.50 & 49.80 & 96.9 & 96.35 \\
\hline $\begin{array}{l}\text { Thermal conductivity } \\
\left(\mathrm{W} \cdot \mathrm{m}^{-1} \cdot \mathrm{K}^{-1}\right)\end{array}$ & $0.59-1.74$ & $0.13-0.29$ & $0.30-0.94$ & $\begin{array}{c}0.04-0.70 \\
\text { see Figure } 6\end{array}$ & $\begin{array}{c}0.05-0.45 \\
\text { see Figure } 6\end{array}$ \\
\hline $\begin{array}{l}\text { Specific heat capacity } \\
\left(\mathrm{J} \cdot \mathrm{kg}^{-1} \cdot \mathrm{K}^{-1}\right)\end{array}$ & $825-1254$ & $1501-2733$ & 1054-1592 & $810-3850$ & 2130 \\
\hline $\begin{array}{l}\text { Water vapor diffusion } \\
\text { resistance factor (-) }\end{array}$ & $8.8-22.1$ & 31.99-134.85 & $5.52-7.52$ & $1.2-2.4$ & $1.12-2.69$ \\
\hline $\begin{array}{l}\text { Moisture diffusivity } \\
\qquad\left(\mathrm{m}^{2} \cdot \mathrm{s}^{-1}\right)\end{array}$ & $1.08 \times 10^{-6}$ & $1.04 \times 10^{-9}$ & $3.27 \times 10^{-8}$ & $8.50 \times 10^{-6}$ & $1.14 \times 10^{-6}$ \\
\hline $\begin{array}{l}\text { Hygroscopic moisture } \\
\text { content }\left(\mathrm{m}^{3} \cdot \mathrm{m}^{-3}\right)\end{array}$ & 0.0036 & 0.0342 & 0.0144 & $\begin{array}{c}0.0003 \\
\text { see Figure } 7\end{array}$ & $\begin{array}{c}0.0031 \\
\text { see Figure } 7\end{array}$ \\
\hline
\end{tabular}

Figure 6 depicts the thermal conductivity of mineral wool and wood fibers as a function of moisture content. These results were obtained experimentally on a set of samples. A slight variation of results might be observed, which can be ascribed to measurement uncertainties or specifics of natural fiber materials such as various sample compression. Figure 7 shows the sorption isotherms, i.e., experimentally determined moisture content of the material when exposed to the environment with specific relative humidity. The experimental results were approximated using exponential functions. 


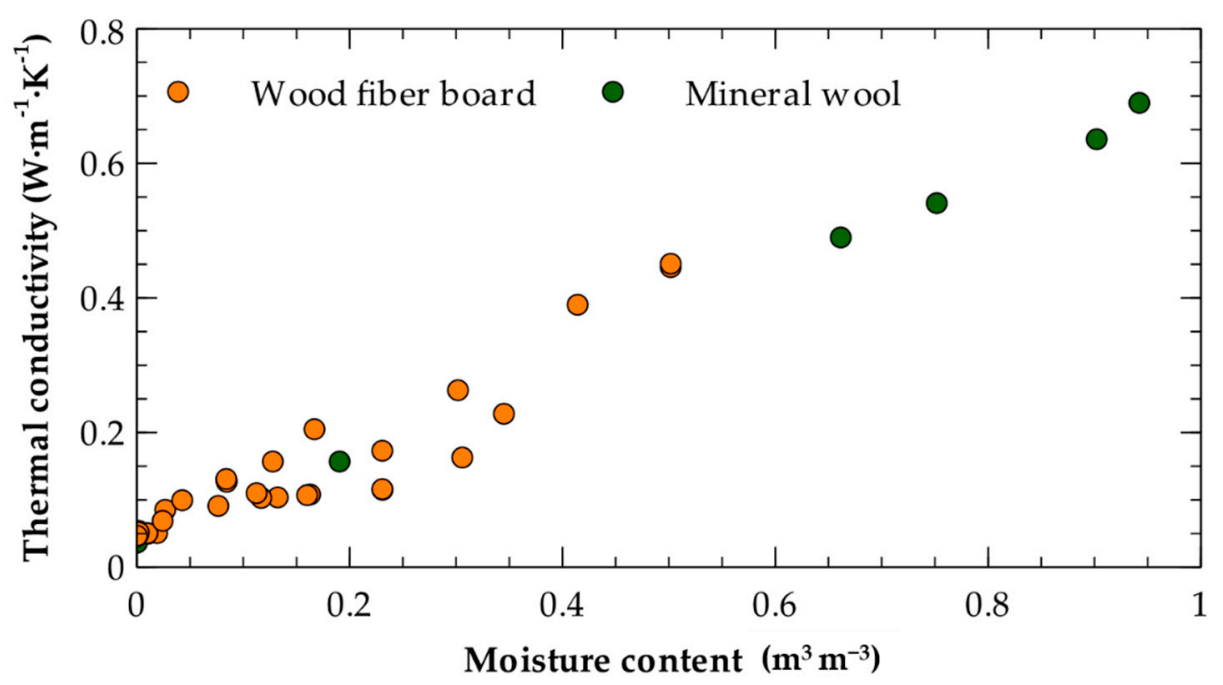

Figure 6. Heat transport properties of thermal insulations.

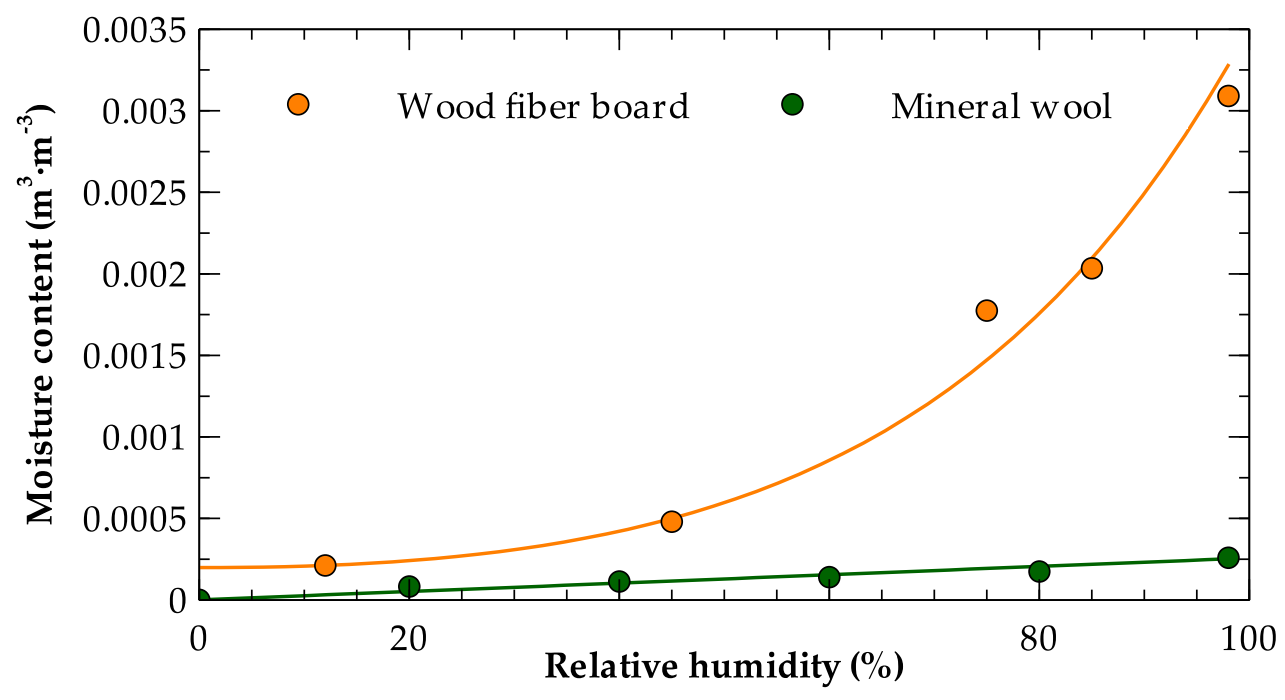

Figure 7. Water vapor storage properties of thermal insulations.

\subsection{Boundary Conditions}

The quality of boundary conditions is very important from the point of view of the accuracy of computational results obtained. In order to capture a real performance of the assemblies when exposed to weather conditions, a weather data set is applied on the exterior side in form of TRY (Test Reference Year), which contains hourly average values of temperature, relative humidity, rainfalls, sun radiation (direct and diffuse), wind velocity, and wind direction. This data is evaluated based on a long-term observation of the weather parameters mentioned. Being constructed by the Czech Hydrometeorological Institute, the TRY is based on at least a 30-year data set.

The climatic conditions of Olomouc, Czech Republic was used within this paper, as it is a historic city thus with a higher number of historical and traditional buildings. The summary of weather data is given in Table 2 and Figures 8 and 9. Constant relative humidity $(55 \%)$ and temperature $\left(21^{\circ} \mathrm{C}\right)$ were applied on the interior side according to prescribed standard conditions [50]. 
Table 2. Summary of weather parameters, Olomouc, Czech Republic.

\begin{tabular}{|c|c|c|}
\hline \multicolumn{2}{|c|}{ Parameter } & Value \\
\hline \multirow{4}{*}{$\begin{array}{l}\text { Temperature } \\
\text { (see Figure 8) }\end{array}$} & Average & $9.8^{\circ} \mathrm{C}$ \\
\hline & Maximal & $34.1^{\circ} \mathrm{C}$ \\
\hline & Minimal & $-13.9^{\circ} \mathrm{C}$ \\
\hline & $20-25^{\circ} \mathrm{C}$ zone & $857 \mathrm{~h}$ \\
\hline \multirow{2}{*}{$\begin{array}{l}\text { Relative humidity } \\
\text { (see Figure 8) }\end{array}$} & Average & $76.0 \%$ \\
\hline & $80 \%-100 \%$ zone & $4314 \mathrm{~h}$ \\
\hline \multicolumn{2}{|c|}{ Rainfalls } & $570.9 \mathrm{~mm}$ \\
\hline \multicolumn{2}{|c|}{ Wind } & see Figure 9a \\
\hline \multicolumn{2}{|c|}{ Sun radiation } & see Figure $9 b$ \\
\hline
\end{tabular}

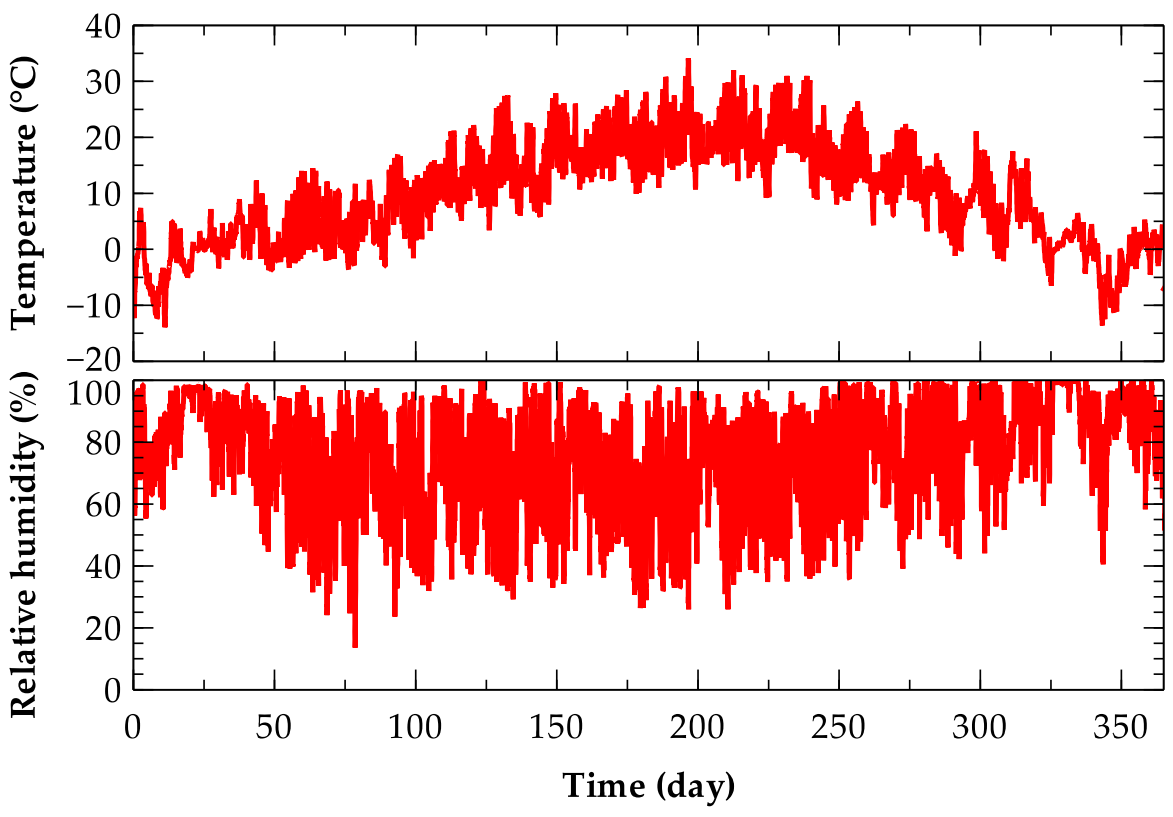

Figure 8. Reference weather data of Olomouc, Czech Republic: temperature and relative humidity.
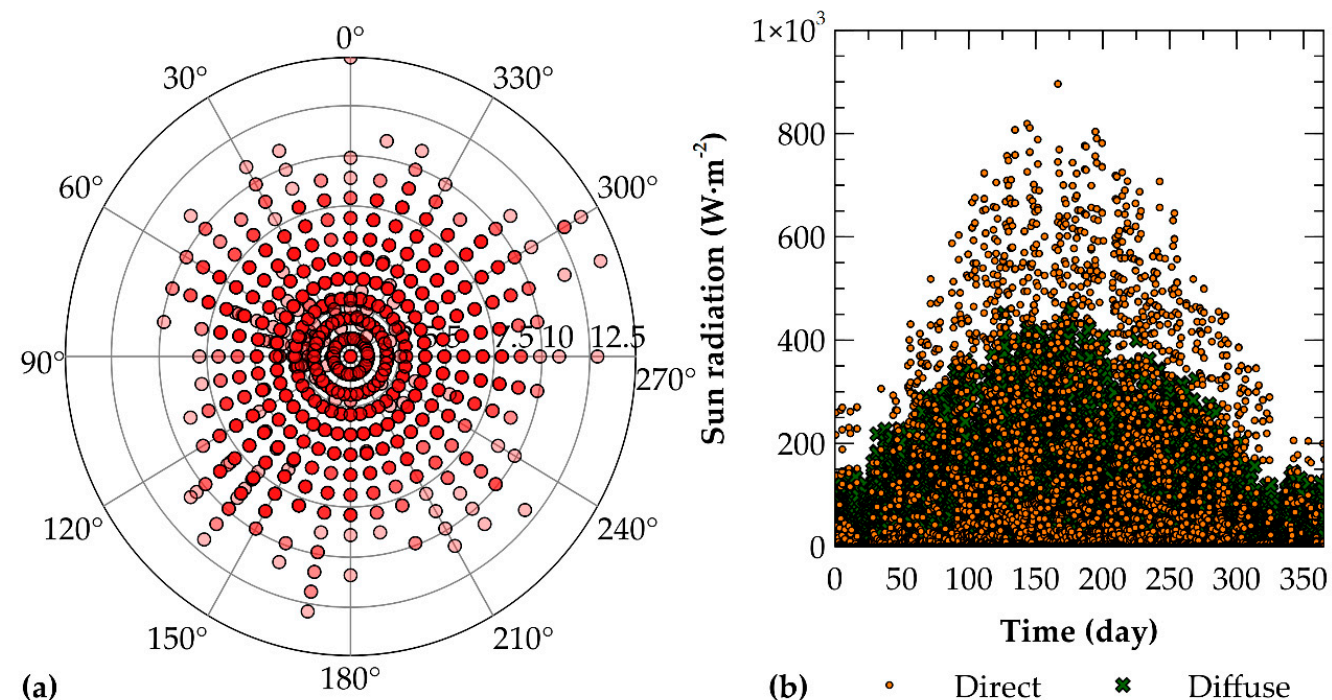

(b) $\quad$ Direct $*$ Diffuse

Figure 9. Reference weather data of Olomouc, Czech Republic: (a) summary of wind velocities and directions; (b) summary of sun radiation. 


\section{Results and Discussion}

According to the results of the computational modeling, the presence of the thermal insulation placed on the interior side of the masonry definitely affects the hygrothermal performance of the wall assemblies. As a side effect, the reduction of the heat flux through the wall due to low thermal conductivity of the insulating materials contributed to masonry temperature decrease over the year as it is no longer supplied by the interior heat in such an extent as in the case of a plain wall or a wall provided with an exterior insulation. Moreover, the position of the thermal insulation on the interior side does not protect the wall against weather conditions. Such an exposed wall must face extensive temperature and moisture fluctuations as it is protected only by the exterior plaster. Its hygric and thermal properties are therefore essential to mitigate this straining. To see the temperature fluctuations, contour fill images of the walls are depicted in Figures 10 and 11, capturing the temperature distribution in different sessions of the reference year. Due to the high number of images and low differences between temperature distributions of particular walls assemblies, only two variations are shown: masonry with the wooden beam end provided with the thermal insulation made of wood fibers (Figure 10) and the window jamb provided with the thermal insulation made of mineral wool (Figure 11).

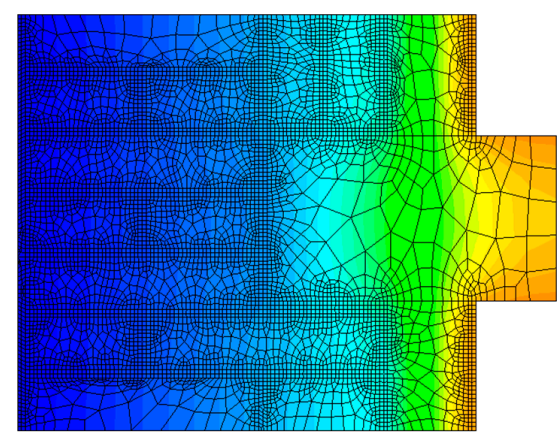

(a)

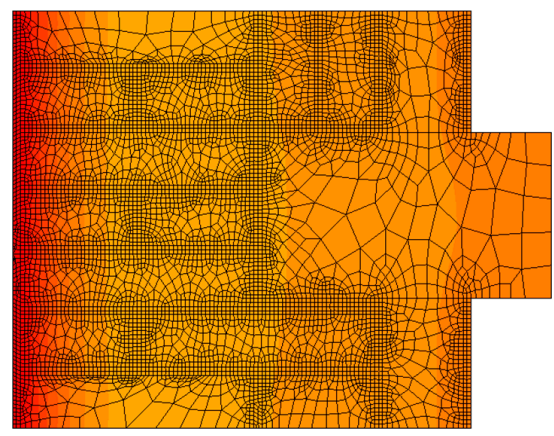

(c)

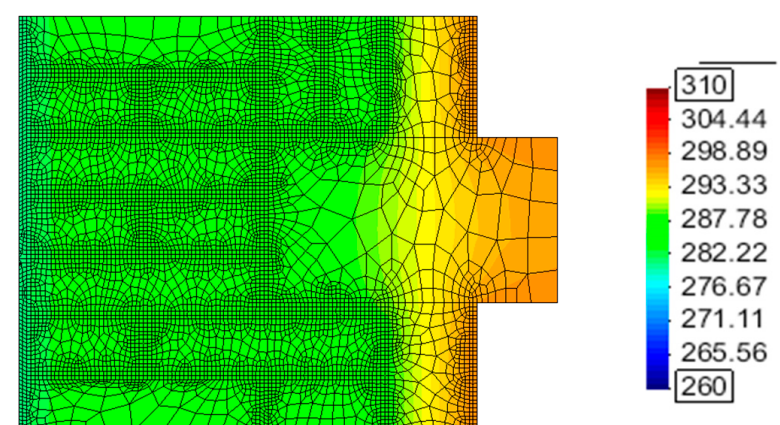

(b)

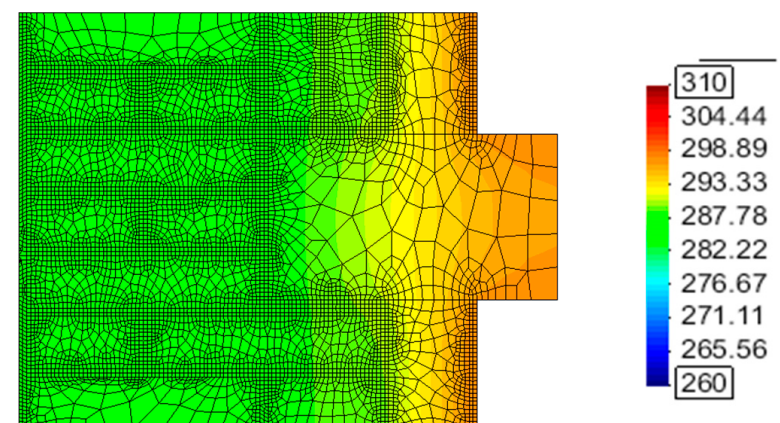

(d)

Figure 10. Temperature distribution $(\mathrm{K})$ over the masonry and wooden beam end provided with interior thermal insulation made of wood fibers: (a) 9 January, 16:00, (b) 10 April, 22:00, (c) 11 July, 11:00, and (d) 10 October, 10:00. The temperature values were obtained using computational modeling technique described in Section 4.

It can be clearly seen the extensive thermal straining of the wall assemblies investigated, the outer layers in particular. The temperature may vary within the reference year between $-10.96{ }^{\circ} \mathrm{C}$ and $38.66^{\circ} \mathrm{C}$, which represents a difference of nearly $50^{\circ} \mathrm{C}$. However, comparing Figure $10 \mathrm{a}$,c, significant temperature differences may be observed across the whole thickness of the masonry.

The distribution of the relative humidity is depicted in Figures 12 and 13 using contour fills as well. In this case, only two variations are shown due to a similarity of results: masonry with the wooden beam end provided with thermal insulation made of mineral wool (Figure 12) and the window jamb provided with thermal insulation made of wood fibers (Figure 13). 


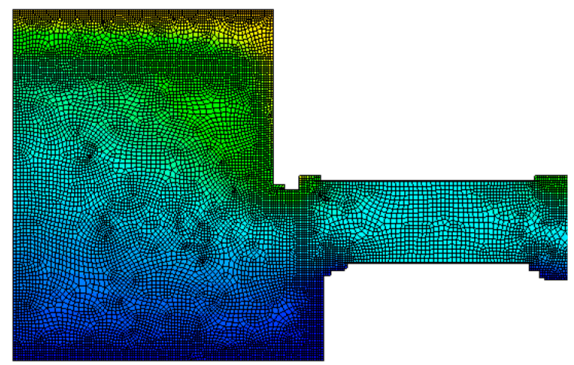

(a)

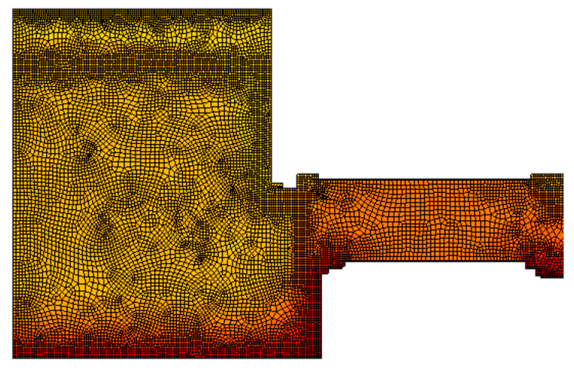

(c)

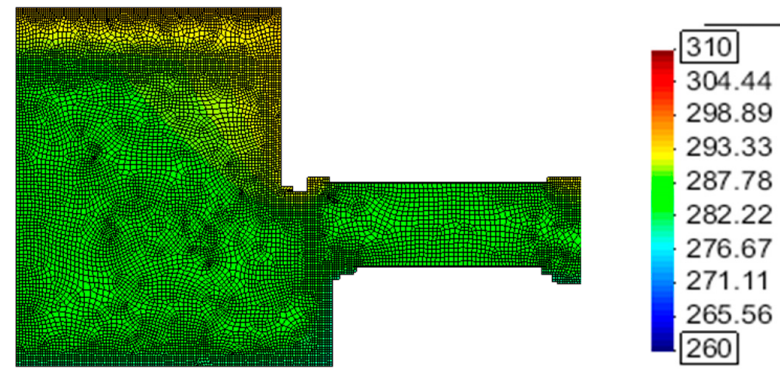

(b)

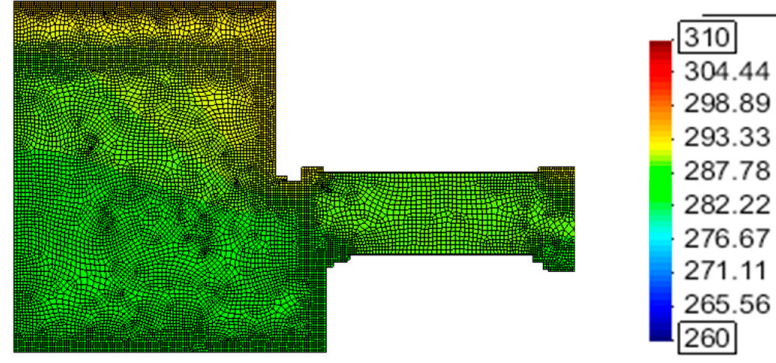

(d)

Figure 11. Temperature distribution (K) over the window jamb provided with the interior thermal insulation made of mineral wool: (a) 9 January, 16:00, (b) 10 April, 22:00, (c) 11 July, 11:00, and (d) 10 October, 10:00. The temperature values were obtained using computational modeling technique described in Section 4.

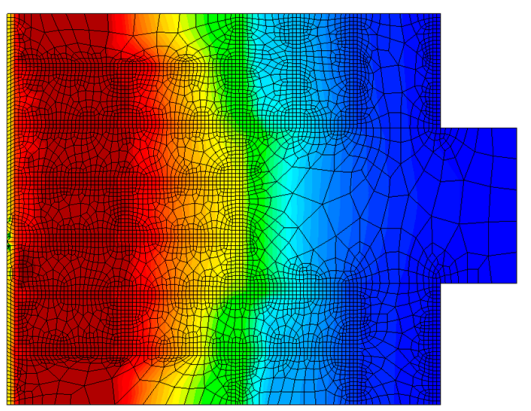

(a)

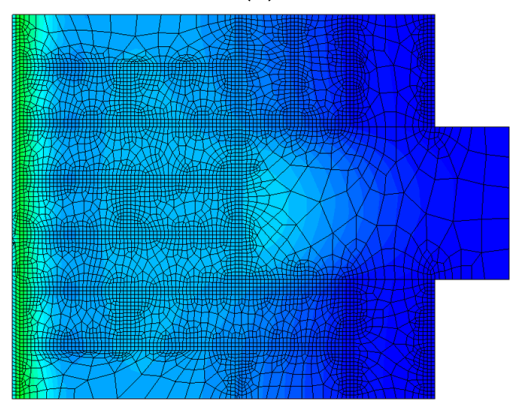

(c)

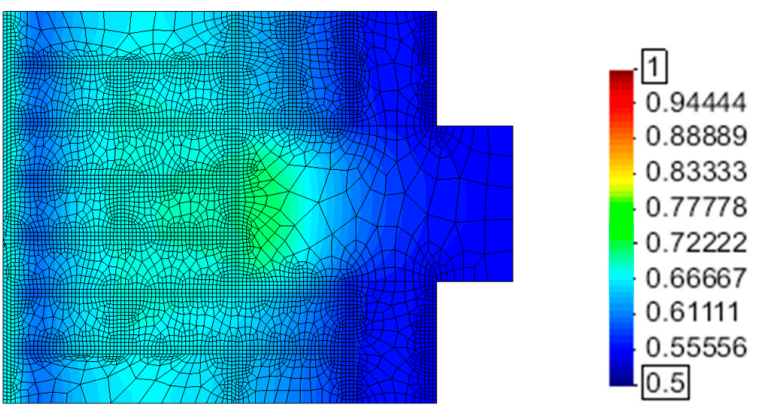

(b)

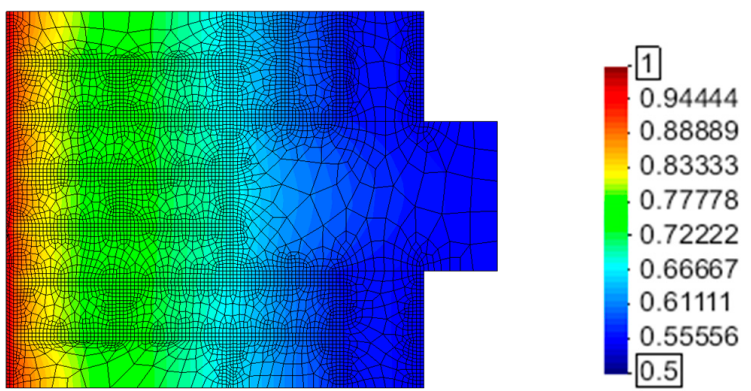

(d)

Figure 12. Relative humidity distribution (-) over the masonry and wooden beam end provided with interior thermal insulation made of mineral wool: (a) 9 January, 16:00, (b) 10 April, 22:00, (c) 11 July, 11:00, and (d) 10 October, 10:00. The relative humidity values were obtained using computational modeling technique described in Section 4. 


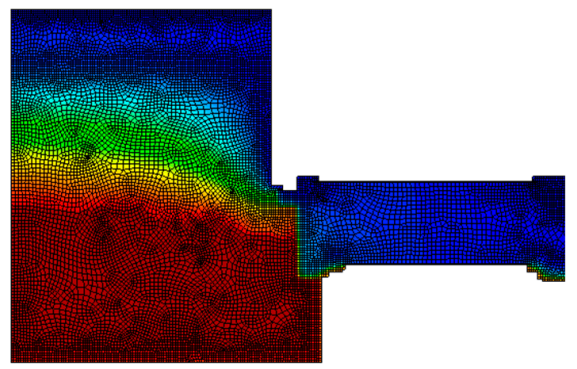

(a)

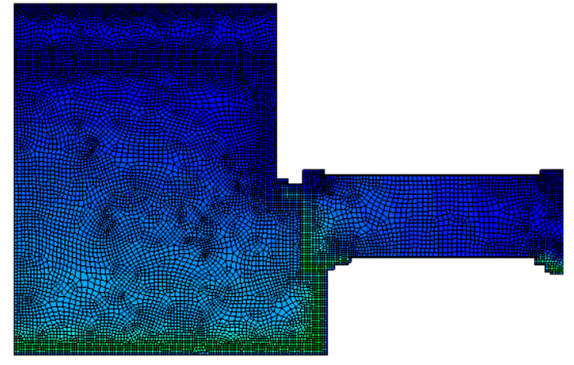

(c)

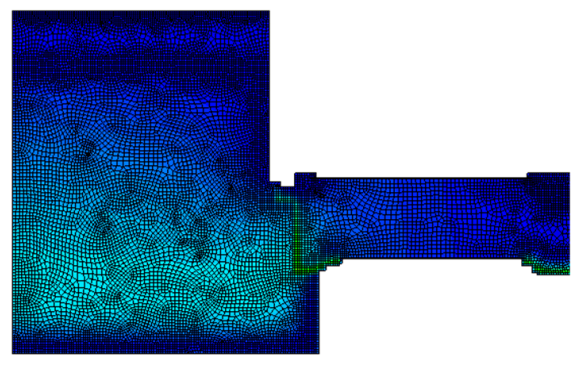

(b)

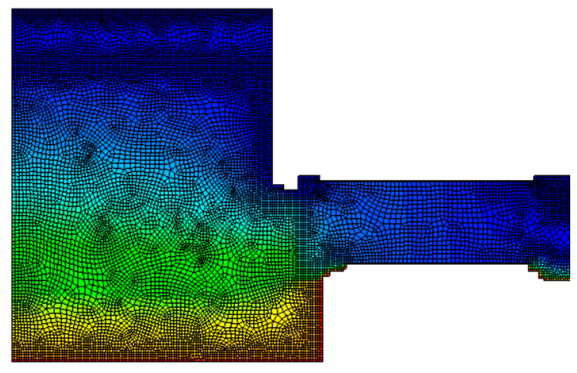

(d)
0.72222

0.66667

0.61111

0.55556

0.5

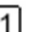

0.94444

0.88889

0.83333

0.77778

0.72222

0.66667

0.61111

0.55556

0.5

Figure 13. Relative humidity distribution (-) over the window jamb provided with the interior thermal insulation made of wood fibers: (a) 9 January, 16:00, (b) 10 April, 22:00, (c) 11 July, 11:00, and (d) 10 October, 10:00. The relative humidity values were obtained using computational modeling technique described in Section 4.

The distribution of the relative humidity depicted in Figures 12 and 13 proves that the masonry is prone to increased moisture straining. Since the thermal insulation is not present on the exterior side and thus does not reduce the moisture income, the water can easily penetrate to deeper layers of the masonry. This phenomenon is significant especially due to wind-driven rain [51]. Generally, it means the moisture contained in the walls is higher when compared to masonry with exterior thermal insulation. Such a finding was reported, e.g., by Orlik-Kożdon and Steidl [52] who investigated the impact of interior thermal insulation on the hygrothermal performance of a brick wall. Using EPS as the insulation material, they reported the average monthly values of relative humidity to be between $65 \%$ and $78 \%$, depending on the month. This corresponds with the results presented in this paper. Such high long-term values might represent certain kinds of risks for the beam end present in the masonry. It can be also seen in Figure $12 \mathrm{~b}$ that moisture is kept around the beam end for a longer period of time after it penetrates through the surface. It happens due to a high value of the hygroscopic moisture content of the wood $\left(0.0342 \mathrm{~m}^{3} \cdot \mathrm{m}^{-3}\right.$, see Table 1$)$, which makes it more capable to absorb and retain moisture. Fungi colonization, mold growth, and wood decay might then appear, especially when the relative humidity is kept above $81 \%$ and $90 \%$, respectively [53]. This was also approved by Kopecky et al. [54] who revealed small spots of mold on the beam during an experimental investigation even when exposed to mild weather conditions.

The assessment of conditions convenient for biofilms growth on the exterior surfaces is given in Figure 14. Here, all the variations investigated are summarized together. The diagrams show the hygrothermal conditions on the surface of each detail, being compared to favorable growth conditions for particular categories of biofilms described in Section 3. 

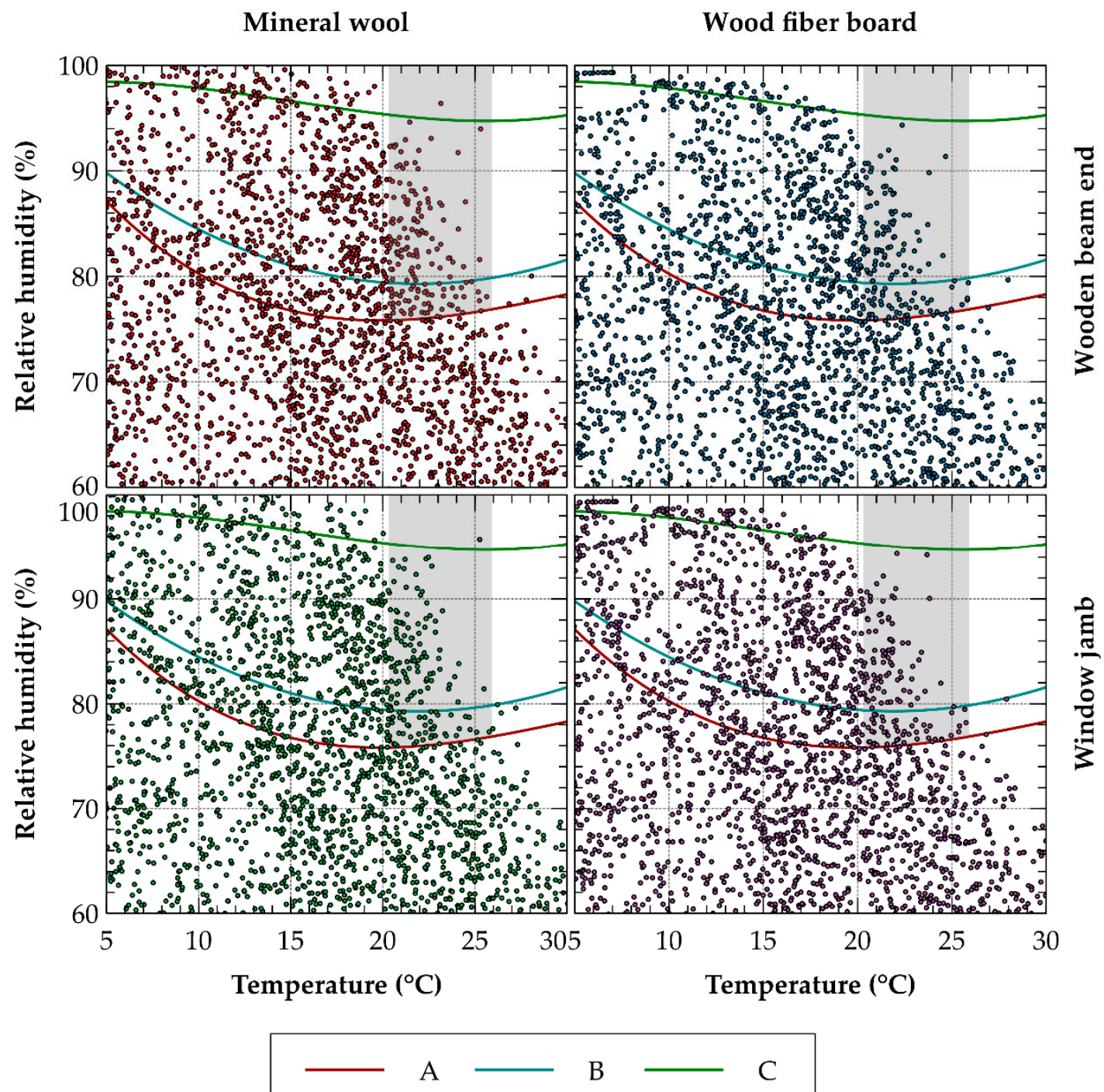

Figure 14. Assessment of hygrothermal conditions favorable for biofilms growth. All the variations investigated are presented. Left column-mineral wool; right column-wood fiber board; 1 st row-wooden beam end; 2 nd row-window jamb. The lines A, B, and C mark various growth-demanding nature of biofilms, as described in Section 3. The dots show the hourly values of relative humidity and temperature obtained using computational modeling described in Section 4 .

Based on results presented in Figure 14, it is obvious that, during the reference year, all the wall assemblies investigated offer favorable conditions for the biofilms' growth on the exterior surface. Depending on the requirements of the biofilms on the moisture conditions, one can count up to $180 \mathrm{~h}$ a year when both hygrothermal and light conditions enable the growth. A longer duration of favorable conditions was found in the case of wood beam end detail. Moreover, the walls insulated using mineral wool provided more favorable conditions than those with wood fibers. This proves the fact that thermal insulation placed on the interior side may affect hygrothermal conditions also on the exterior surface as it affects overall heat and moisture transport and storage parameters of a wall. However, due to similar material properties of the thermal insulations presented in Table 1, the differences in the surface conditions and thus in the duration of convenient growth conditions are not as significant. The summary of the duration of hygrothermal conditions favorable for the biofilms' growth is given in Table 3. 
Table 3. Duration of favorable conditions for biofilms growth (h).

\begin{tabular}{ccccc}
\hline Type of Detail & Thermal Insulation & A & B & C \\
\hline Wooden beam end & Mineral wool & 180 & 120 & 1 \\
Wooden beam end & Wood fiber board & 154 & 101 & 0 \\
Window jamb & Mineral wool & 170 & 116 & 1 \\
Window jamb & Wood fiber board & 153 & 98 & 0 \\
\hline
\end{tabular}

The number of hours with favorable growth conditions is relatively low in general. One must also consider that the growth conditions were derived from growth conditions determined for molds, either xerophilic (dry loving) or hydrophilic (wet loving). Even if the growth conditions were tailored to biofilms containing green algae and cyanobacteria by adjusting the favorable temperature range and by limiting to daylight periods, the results presented in Table 3 have still an approximate character. Since the biofilms are rather of a hydrophilic nature, it means, somewhat between B and C types, the real numbers could be even lower. The growth model used does not include a time of exposure to favorable growth conditions. Therefore, precise conclusions cannot be drawn. Anyway, the results may indicate that masonry provided with interior thermal insulation does not have to struggle with the biofilms' growth on their exterior surface when designed properly. Even if the interior thermal insulation contributes to increased hygrothermal straining, the favorable hygrothermal patterns are met only occasionally as high temperatures are reached mostly in summer periods, while high relative humidity in the winter ones. This might be the reason why other researchers do not mention the problem of biofilms growth on exterior surfaces at all and rather focus on different specifics of interior thermal insulation systems $[12,52,54]$.

The excessively favorable growth conditions might appear only when an additional moisture source will be present. Water leakage, splashing water, or missing waterproofing are typical examples in that respect that might condition the biofilm growth on the exterior surface. Improper building utilization, poor ventilation, or thermal bridges in the construction, on the other hand, might cause biofilm growth in interiors.

\section{Conclusions}

A numerical analysis of the hygrothermal performance of selected critical details was presented in this paper. Using two-dimensional computational modeling of coupled heat and moisture transport, the distribution of heat and moisture over during a reference year was estimated and evaluated from the point of view of possible risks of biofilms growth. Wooden beam end joint to brick masonry and a window jamb with a window frame were assumed being provided either with mineral wool or wood fiberboard from the interior side. Such details were exposed to the dynamic climatic conditions of Olomouc, Czech Republic.

The results obtained within this research indicate there might only be a small risk of biofilm growth on the exterior surface of the critical details provided with interior thermal insulations. Combining the hygrothermal conditions on the surface with an adjusted isopleth growth model, up to $180 \mathrm{~h}$ of favorable growth conditions were detected in the reference year. This number was obtained for the worst scenario assuming xerophilic organisms. However, since biofilms are mostly formed by green algae and cyanobacteria, which tend to be rather hydrophilic, the duration of convenient conditions will more likely smaller. Comparing particular variations investigated, it was found out that mineral wool has a worse impact on the exterior surface conditions than wood fibers. Analogously, the wooden beam detail is more prone to biofilms growth than the window jamb.

Anyway, the level of risk of external surface biofilms covering is generally very low when a proper design is assumed. Therefore, other aspects of interior thermal insulation systems should be rather focused on instead. Wood decay and mold growth elimination belong among the most important aspects in that respect. 
Author Contributions: Conceptualization, V.K. and J.K.; methodology, V.K.; software, J.M. and J.K.; validation, J.Ž., J.K., and J.M.; formal analysis, R.Č.; investigation, V.K., J.Ž., and R.Č.; resources, V.K. and J.Ž.; data curation, V.K. and J.K.; writing—original draft preparation, V.K.; writing-review and editing, J.K. and R.Č.; visualization, V.K.; supervision, R.Č.; project administration, J.M.; funding acquisition, V.K. and J.Ž. All authors have read and agreed to the published version of the manuscript.

Funding: This research has been supported by the Czech Science Foundation, under project No. 19-01558S and by the Ministry of Education, Youth and Sports of the Czech Republic, under the specific university research project No. SVV201907 of the Institute of Technology and Business in České Bud'ejovice.

Conflicts of Interest: The authors declare no conflicts of interest.

\section{References}

1. Cansino, J.M.; Pablo-Romero, M.P.; Roman, R.; Yniguez, R. Promoting renewable energy sources for heating and cooling in EU-27 countries. Energy Policy 2011, 39, 3803-3812. [CrossRef]

2. European Union (EU). Energy Performance of Building Directive II; The European Parliament and the council of the European Union: Brussels, Belgium, 2010.

3. Giada, G.; Caponetto, R.; Nocera, F. Hygrothermal properties of raw earth materials: A literature review. Sustainability 2019, 11, 5342. [CrossRef]

4. Murmu, A.L.; Patel, A. Towards sustainable bricks production: An overview. Constr. Build. Mater. 2018, 165, 112-125. [CrossRef]

5. Qu, X.L.; Zhao, X.G. Previous and present investigations on the components, microstructure and main properties of autoclaved aerated concrete-A review. Constr. Build. Mater. 2017, 135, 505-516. [CrossRef]

6. Kim, J.T.; Yu, C.W.F. Sustainable development and requirements for energy efficiency in buildings-The Korean perspectives. Indoor Built Environ. 2018, 27, 734-751. [CrossRef]

7. Kamel, E.; Memari, A.M. State-of-the-Art review of energy smart homes. J. Archit. Eng. 2019, 25. [CrossRef]

8. Barreira, E.; de Freitas, V.P. External thermal insulation composite systems: Critical parameters for surface hygrothermal behaviour. Adv. Mater. Sci. Eng. 2014, 2014, 650752. [CrossRef]

9. Vereecken, E.; Roels, S. Capillary active interior insulation: Do the advantages really offset potential disadvantages? Mater. Struct. 2015, 48, 3009-3021. [CrossRef]

10. Webb, A.L. Energy retrofits in historic and traditional buildings: A review of problems and methods. Renew. Sustain. Energy Rev. 2017, 77, 748-759. [CrossRef]

11. Vereecken, E.; Van Gelder, L.; Janssen, H.; Roels, S. Interior insulation for wall retrofitting-A probabilistic analysis of energy savings and hygrothermal risks. Energy Build. 2015, 89, 231-244. [CrossRef]

12. Orlik-Kożdoń, B. Interior insulation of masonry walls—selected problems in the design. Energies 2019, 12, 3895. [CrossRef]

13. Vereecken, E.; Roels, S. A comparison of the hygric performance of interior insulation systems: A hot box-cold box experiment. Energy Build. 2014, 80, 37-44. [CrossRef]

14. Vereecken, E.; Roels, S. Wooden beam ends in combination with interior insulation: An experimental study on the impact of convective moisture transport. Build. Environ. 2019, 148, 524-534. [CrossRef]

15. Guiamet, P.; Crespo, M.; Lavin, P.; Ponce, B.; Gaylarde, C.; de Saravia, S.G. Biodeterioration of funeral sculptures in La Recoleta Cemetery, Buenos Aires, Argentina: Pre- and post-intervention studies. Colloids Surf. B Biointerfaces 2013, 101, 337-342. [CrossRef] [PubMed]

16. Villegas-Sanchez, R.; Arroyo, F. The cathedral of Jerez De La Frontera (Cadiz, Spain): Stone degradation and conservation. J. Cult. Herit. 2013, 14, E113-E116. [CrossRef]

17. Jurado, V.; Miller, A.Z.; Cuezva, S.; Fernandez-Cortes, A.; Benavente, D.; Rogerio-Candelera, M.A.; Reyes, J.; Canaveras, J.C.; Sanchez-Moral, S.; Saiz-Jimenez, C. Recolonization of mortars by endolithic organisms on the walls of San Roque church in Campeche (Mexico): A case of tertiary bioreceptivity. Constr. Build. Mater. 2014, 53, 348-359. [CrossRef]

18. Becerra, J.; Ortiz, P.; Zaderenko, A.P.; Karapanagiotis, I. Assessment of nanoparticles/nanocomposites to inhibit micro-algal fouling on limestone facades. Build. Res. Inf. 2020, 48, 180-190. [CrossRef]

19. Zarzuela, R.; Carbu, M.; Gil, M.L.A.; Cantoral, J.M.; Mosquera, M.J. Ormosils loaded with SiO2 nanoparticles functionalized with Ag as multifunctional superhydrophobic/biocidal/consolidant treatments for buildings conservation. Nanotechnology 2019, 30, 18. [CrossRef] 
20. Misra, A.; Castillo, I.F.; Muller, D.P.; Gonzalez, C.; Eyssautier-Chuine, S.; Ziegler, A.; de la Fuente, J.M.; Mitchell, S.G.; Streb, C. Polyoxometalate-ionic liquids (POM-ILs) as anticorrosion and antibacterial coatings for natural stones. Angew. Chem. Int. Ed. 2018, 57, 14926-14931. [CrossRef]

21. Vojtkova, H. Algae and their biodegradation effects on building materials in the Ostrava industrial agglomeration. In Proceedings of the 1st International Conference on Advances in Environmental Engineering (AEE), Ostrava, Czech Republic, 28-30 November 2017.

22. Rosado, T.; Silva, M.; Galvao, A.; Mirao, J.; Candeias, A.; Caldeira, A.T. A first insight on the biodegradation of limestone: The case of the World Heritage Convent of Christ. Appl. Phys. A Mater. Sci. Process 2016, $122,7$. [CrossRef]

23. Guillitte, O.; Dreesen, R. Laboratory chamber studies and petrographic analysis as bioreceptivity assessment tools of building-materials. Sci. Total Environ. 1995, 167, 365-374. [CrossRef]

24. Segers, F.J.J.; van Laarhoven, K.A.; Wosten, H.A.B.; Dijksterhuis, J. Growth of indoor fungi on gypsum. J. Appl. Microbiol. 2017, 123, 429-435. [CrossRef] [PubMed]

25. Shirakawa, M.A.; Beech, I.B.; Tapper, R.; Cincotto, M.A.; Gambale, W. The development of a method to evaluate bioreceptivity of indoor mortar plastering to fungal growth. Int. Biodeterior. Biodegrad. 2003, 51, 83-92. [CrossRef]

26. Tran, T.H.; Hoang, N.D. Predicting colonization growth of algae on mortar surface with artificial neural network. J. Comput. Civil Eng. 2016, 30, 8. [CrossRef]

27. Tran, T.H.; Hoang, N.D. Estimation of algal colonization growth on mortar surface using a hybridization of machine learning and metaheuristic optimization. Sadhana Acad. Proc. Eng. Sci. 2017, 42, 929-939. [CrossRef]

28. Marquez-Penaranda, J.F.; Sanchez-Silva, M.; Husserl, J.; Bastidas-Arteaga, E. Effects of biodeterioration on the mechanical properties of concrete. Mater. Struct. 2016, 49, 4085-4099. [CrossRef]

29. Graziani, L.; Quagliarini, E.; Osimani, A.; Aquilanti, L.; Clementi, F.; D’Orazio, M. The influence of clay brick substratum on the inhibitory efficiency of $\mathrm{TiO} 2$ nanocoating against biofouling. Build. Environ. 2014, 82, 128-134. [CrossRef]

30. Gaylarde, C.C.; Gaylarde, P.M. A comparative study of the major microbial biomass of biofilms on exteriors of buildings in Europe and Latin America. Int. Biodeterior. Biodegrad. 2005, 55, 131-139. [CrossRef]

31. Gaylarde, P.M.; Shirakawa, M.A.; John, V.; Gambale, W.; Gaylarde, C.C. Statistical analysis of fungicide activity in paint films on two buildings. Surf. Coat. Int. Part B Coat. Trans. 2004, 87, 261-264. [CrossRef]

32. Gil, M.; Martins, M.R.; Carvalho, M.L.; Souto, C.; Longelin, S.; Cardoso, A.; Mirao, J.; Candeias, A.E. Microscopy and microanalysis of an extreme case of salt and biodegradation in 17 th century wall paintings. Microsc. Microanal. 2015, 21, 606-616. [CrossRef]

33. Rosado, T.; Gil, M.; Caldeira, A.T.; Martins, M.D.; Dias, C.B.; Carvalho, L.; Mirao, J.; Candeias, A.E. Material characterization and biodegradation assessment of mural paintings: Renaissance frescoes from santo aleixo church, southern portugal. Int. J. Arch. Herit. 2014, 8, 835-852. [CrossRef]

34. Barberousse, H.; Ruot, B.; Yepremian, C.; Boulon, G. An assessment of facade coatings against colonisation by aerial algae and cyanobacteria. Build. Environ. 2007, 42, 2555-2561. [CrossRef]

35. Garciapichel, F.; Wingard, C.E.; Castenholz, R.W. Evidence regarding the uv sunscreen role of a mycosporine-like compound in the cyanobacterium gloeocapsa sp. Appl. Environ. Microbiol. 1993, 59, 170-176. [CrossRef]

36. Tiano, P.; Accolla, P.; Tomaselli, L. Phototrophic biodeteriogens on lithoid surfaces-An ecological study. Microbial Ecol. 1995, 29, 299-309. [CrossRef] [PubMed]

37. Künzel, H.M.; Sedlbauer, K. Biological growth on stucco. In Proceedings of the Buildings VIII/Proceedings, Atlanta, GA, USA, 2-7 December 2001; pp. 1-5.

38. Kobetičová, K.; Nábělková, J.; Kočí, V. Identification of biofilm composition covering lime-based materials. MATEC Web Conf. 2019, 282, 02067. [CrossRef]

39. Vereecken, E.; Roels, S. Review of mould prediction models and their influence on mould risk evaluation. Build. Environ. 2012, 51, 296-310. [CrossRef]

40. Rowan, N.J.; Johnstone, C.M.; McLean, R.C.; Anderson, J.G.; Clarke, J.A. Prediction of toxigenic fungal growth in buildings by using a novel modelling system. Appl. Environ. Microbiol. 1999, 65, 4814-4821. [CrossRef] 
41. Clarke, J.A.; Johnstone, C.M.; Kelly, N.J.; McLean, R.C.; Anderson, J.A.; Rowan, N.J.; Smith, J.E. A technique for the prediction of the conditions leading to mould growth in buildings. Build. Environ. 1999, 34, 515-521. [CrossRef]

42. Dubosc, A.; Escadeillas, G.; Blanc, P.J. Characterization of biological stains on external concrete walls and influence of concrete as underlying material. Cem. Concr. Res. 2001, 31, 1613-1617. [CrossRef]

43. Madera, J.; Koci, J.; Koci, V.; Kruis, J. Parallel modeling of hygrothermal performance of external wall made of highly perforated bricks. Adv. Eng. Softw. 2017, 113, 47-53. [CrossRef]

44. Koci, V.; Koci, J.; Madera, J.; Pavlik, Z.; Gu, X.L.; Zhang, W.P.; Cerny, R. Thermal and hygric assessment of an inside-insulated brick wall: 2D critical experiment and computational analysis. J. Build. Phys. 2018, 41, 497-520. [CrossRef]

45. Jerman, M.; Palomar, I.; Koci, V.; Cerny, R. Thermal and hygric properties of biomaterials suitable for interior thermal insulation systems in historical and traditional buildings. Build. Environ. 2019, 154, 81-88. [CrossRef]

46. Černý, R. Complex System of Methods for Directed Design and Assessment of Functional Properties of Building Materials and its Applications; Czech Technical University: Prague, Czech Republic, 2013; p. 509.

47. Koci, V.; Cachova, M.; Konakova, D.; Vejmelkova, E.; Jerman, M.; Keppert, M.; Madera, J.; Cerny, R. Heat and moisture transport and storage parameters of bricks affected by the environment. Int. J. Thermophys. 2018, 39, 63. [CrossRef]

48. Koci, V.; Madera, J.; Jerman, M.; Zumar, J.; Konakova, D.; Cachova, M.; Vejmelkova, E.; Reiterman, P.; Cerny, R. Application of waste ceramic dust as a ready-to-use replacement of cement in lime-cement plasters: An environmental-friendly and energy-efficient solution. Clean Technol. Environ. Policy 2016, 18, 1725-1733. [CrossRef]

49. Jerman, M.; Cerny, R. Effect of moisture content on heat and moisture transport and storage properties of thermal insulation materials. Energy Build. 2012, 53, 39-46. [CrossRef]

50. Czech Office for Standards, Metrology and Testing. Thermal Protection of Buildings—Part 2: Requirements; Czech Office for Standards, Metrology and Testing: Prague, Czech Republic, 2011.

51. Hansen, T.K.; Bjarlov, S.P.; Peuhkuri, R. The effects of wind-driven rain on the hygrothermal conditions behind wooden beam ends and at the interfaces between internal insulation and existing solid masonry. Energy Build. 2019, 196, 255-268. [CrossRef]

52. Orlik-Kozdon, B.; Steidl, T. Impact of internal insulation on the hygrothermal performance of brick wall. J. Build. Phys. 2017, 41, 120-134. [CrossRef]

53. Schmidt, O. Indoor wood-decay basidiomycetes: Damage, causal fungi, physiology, identification and characterization, prevention and control. Mycol. Progress 2007, 6, 261-279. [CrossRef]

54. Kopecky, P.; Stanek, K.; Bures, M.; Richter, J.; Ryparova, P.; Tywoniak, J. Experimental investigations of wooden beam ends in masonry with interior insulation: Measured data in real-scale experimental walls exposed to semi-continental climatic conditions. J. Build. Phys. 2019, 43, 147-170. [CrossRef] 